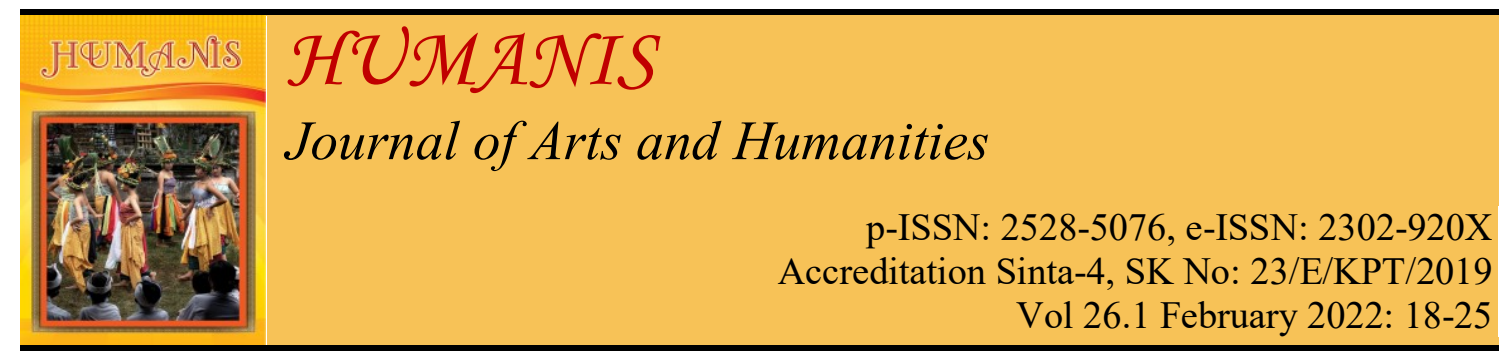

\title{
Pessimistic Strategy in Negative Politeness Study in Thor: Ragnarok Movie
}

\section{Ni Luh Putu Listyari, I Gusti Agung Istri Aryani, Ni Luh Nyoman Seri Malini Udayana University, Denpasar, Bali \\ Correspondence email: putulistyari98@gmail.com, istri_aryani@unud.ac.id, seri.malini@unud.ac.id}

\begin{tabular}{|c|c|}
\hline Article Info & Abstract \\
\hline $\begin{array}{l}\text { Submitted: } 7^{\text {th }} \text { August } 2021 \\
\text { Revised: } 15^{\text {th }} \text { November } 2021 \\
\text { Accepted: } 9^{\text {th }} \text { December } 2021 \\
\text { Keywords: } \\
\text { pessimistic strategy, negative } \\
\text { politeness, movie } \\
\text { Corresponding Author: } \\
\text { Ni Luh Putu Listyari } \\
\text { Email: } \\
\text { putulistyari98@gmail.com } \\
\text { DoI: } \\
\text { https://doi.org/10.24843/JH.20 } \\
\text { 22.v26.i01.p03 }\end{array}$ & $\begin{array}{l}\text { Good communication is the basis of a good relationship. In } \\
\text { achieving the appropriate goals, responses, and reciprocities of } \\
\text { speech, people tend to apply the value of decency. The } \\
\text { pessimistic strategy of negative politeness is analyzed in this } \\
\text { study. The data used in this study is taken from the Thor: } \\
\text { Ragnarok Movie. This study analyzes the type of pessimistic } \\
\text { strategy of negative politeness, such as negative, subjunctive, } \\
\text { and remote-possibility makers. Besides, this study analyzed the } \\
\text { factors that influence the character who used the pessimistic } \\
\text { strategy. Factors are relative force, social distance, and level of } \\
\text { imposition. The analysis of types and factors is based on the } \\
\text { courtesy theory of Brown and Levinson's book "Politeness } \\
\text { Some Universals in Language Usage" (1987). The result } \\
\text { showed that all of the three types of pessimistic strategy in } \\
\text { negative politeness is found in Thor: Ragnarok Movie. The } \\
\text { negative was found in the use of tag questions. The subjunctive } \\
\text { could be found in the use of the would, should, and the use of } \\
\text { the IF clause. The remote-possibility makers was found in the } \\
\text { use of word hope, supposed, though, and perhaps. The most } \\
\text { type pessimistic strategy found in this data is the use of the } \\
\text { subjunctive and the most factor which influences the characters } \\
\text { is the size of imposition. }\end{array}$ \\
\hline
\end{tabular}

\section{INTRODUCTION}

People preserve their relationship with good communication with each other. Greetings, smile to others, and help each other are the way to live happily. Communication is an important thing when people want to fulfil their desire or what they want. The speaker needs to be nice to the hearer, because everyone has their own choice to accepted or rejected the request. Supriyanta's journal (2017) stated that Language is societal which shapes during an interaction and is also shaped by society. That is why the speaker should express their thought beautifully than that good communication could increase the possibility to the hearer accepted the request. For example when your neighbour still has the party at midnight and your baby can not sleep because of noisy neighbours. You could say "hey, stop the music!", this utterance would not work they will reject your request and also being mad at you because you disturb their party. There is another way to lessen the possibility the hearer will reject the request. "hai, would you mind 
to decrease the volume of your music, please? My baby just sleeps now, and I hope you understand it" this utterance is better than before. The speaker extends her emotional, respect to the neighbour event, and also talk with friendliness. Journal by Mahayani (2018) stated that Losing face means the assessment of being embarrassed, humiliated, or disappointed. The face aims for something emotionally laid out that can be lost, cared for, improved, and constantly cared for in communication. It will increase the possibility of the hearer will accept the request. This phenomenon is has a relation with politeness. As stated in Dewi's journal (2017) that politeness is how the speaker appreciates and maintains the situation to the hearer in their interaction. Politeness means knowing how to be nice, tactful, and modest to other people. The politeness in a country is more affected by the culture (Wati,2020).

Based on Brown and Levinson's theory, politeness can be categories into positive and negative politeness. For example, when the speaker wants to ask the hearer to help her solve a question. "hai, I have a question to solve where I know you could do it faster than me. you are the kind person I ever know, and you are the master in math and I know you a perfect person to solve my question" this is how the use of positive politeness and would be different from negative politeness. The speaker will say "I want to ask you a question that I don't understand about and of course, you can feel free to say no. I know you are busy and have some appointment later. If you have a little time before your schedule, it would be amazing if you could help me solve this math task" this utterance is how the use of negative politeness by talking to people without putting them in a bad light and without threatening their face. Kusuma (2014) stated in his journal that Negative politeness speakers assure that the hearer still has their freedom by not showing off, being formal, and restrain the desire. What makes the difference between positive and negative politeness is Positive politeness functions that minimizes the social distance, and Negative politeness functions that indicates social distance. The politeness term has a relation with the theory of face. The face is Like politeness, it can be divided into positive and negative. The positive face is when the speaker needs to be accepted and liked by others and to be treated as a member of the same group. The negative face is a need to have freedom from imposition and make a free choice. Hidayati (2017) stated in her thesis that by being conscious of the faces of others, socially described as a term of familiarity, friendship, or solidarity. That the relation of politeness and face is the politeness is a way to save the face. Besides, Dibyo in his journal (2019), asserts that a politeness strategy is used when a face-threatening act occurs in an interaction. When the speaker wants to save others positive face that they should use the positive politeness and the same way the negative politeness is to save the negative face of the hearer. Gilks states in his journal(2010) that While interacting, these concepts are threatened to some extent, leading to the emergence of the term FTA, requiring the use of polite strategies to maintain harmony and sanity in the face. sNegative politeness is divided into ten strategies. They are indirect, hedge, pessimistic, minimize the imposition, give difference, apologize, personalization, state the FTA (Face threatening Act), nominalize, and go on record. When the speakers used negative politeness, they assume that the hearer not willing to do the request, then the speaker would be more polite to save the negative face. On the other hand, Ulfa stated that Self-effacement, formality, and restraint are characteristics of 
negative politeness. Attention to a limited aspect of the hearer's self-image focusing on H's want to be unimpeded (2019). When the speaker does not want the guest to stay in his private room, for illustration, he would say "oh, it is really hot here, would you close the door, please?" in this utterance the speaker speaks indirectly by assuming that the hearer not willing to go out but he speaks indirectly. Politeness could decide whether or not the communication keeps going (Trimandala,2016). By being indirectly redressing the negative face. If the speakers speak directly, it could be "hey, go out from here. It's weird together with you here" It's quite a difference. Whereas, Aseptari stated in her journal (2012) that learning politeness include not only the use of languages but also all the community's social and cultural norms.

Politeness could be analysed in a movie. because the movie has utterance by each character and it has its context. It would be easier to analysed and the status, background, and history of the characters have been defined in the movie. Every person wants to be treated politely by others. Based on those phenomena, this study analysed the negative politeness in the movie. from the ten strategies of negative politeness, this study focuses on the pessimistic strategy only. Besides the type of pessimistic strategy, the factors that influence the character used the pessimistic strategy were also analysed in this study.

\section{METHOD AND THEORY}

In this study, the data is taken from Thor: Ragnarok Movie. This movie is the third series of Thor Movie. It is actioncomedy movie produce by Marvel studios company. It used as data source because it consisted of negative politeness as in the phenomenon which is the interest of this study.
This study focus on the pessimistic strategy is negative politeness. The use of pessimistic strategy is the major data found in this movie. the type of pessimistic strategy and the factors that influence the characters who used those strategies were analysed in this study.

The data were collected by notetaking while watching the movie. The utterance by the characters should be synchronized with the theory used in this study. The collected data is listed before starting analysing it.

This study used a descriptive method in analysing the data. First, the collected data were matched to the theory of pessimism and analysed the use of the pessimistic strategy. Second, described the factors that influence the characters in using the pessimistic strategy.

Brown and Levinson (1987: 129-30) defined negative politeness as the action to maintain the addressee's negative face: he wants to have freedom of action unhindered and his attention unimpeded. Putra stated in his journal (2018) that the speaker wants all of his instruction to be carried out and resulting in good cooperation. Unlike positive politeness, which functions to minimize the social distance, negative politeness is used to indicate social distancing. Journal by Hartati stated that intonation plays a significant role in indicating pessimism. Negative politeness is expanding the social distance yet still showing respect behaviour towards the addressee (2020).

According to Hariri's (2017) thesis, a speaker's desire to express positiveness, concern for the addressee's face, or the speaker's intention to safeguard his own face is required when speaking. Another type of redressing H's negative face want is when the proposed FTA entails forecasting an act of H's negative face want. This can be done on the one hand by clearly offering him the option not to execute the act $\mathrm{A}$, and on the other hand by avoiding coercing H's answer. Thesis 
by Norra stated (2015) that politeness relates to the idea of such thoughtful, humble, and considerate in terms of relationships with others. Be pessimistic is the third technique of negative politeness, which involves $\mathrm{S}$ presuming $\mathrm{H}$ is unlikely to do A. This method redresses H's negative face by expressly expressing doubt that the circumstances for S's speech act's appropriateness exist.. Widiadnyana (2016) stated in his journal that negative politeness could indicate that the speaker is aware and respects the social distance between the speaker and hearer.

Brown and Levinson mention in their book on page 175, three important realizations of the strategy $\mathrm{Be}$ Pessimistic: The Use of The Negative, The Use of The Subjunctive, and The Use of Remote-Possibility Markers.

\section{The Use of Negative}

The circumstance of Negative should not be used in such a way that it is evident that the action requested can be carried out. The speaker shows his doubt to the hearer by put tag particles. The speaker (S) presupposes that the hearer (H) usually do A.

\section{The Use of Subjunctive}

Brown and Levinson in their book stated The subjunctive is a unique and rather uncommon verb form that communicates desire or imagination. The subjunctive is used primarily when discussing occurrences that are not guaranteed to occur. It could mean "wishes to happen," "expects to happen," or "imagines to happen.".

The form of the subjunctive is the base of the verb, the base subjunctive does not use any other form like goes, does, sings. For example;

(1) $\{$ could/would/might $\}$ you do A?

(2) Could you jump over that fivefoot fence?

\section{The Use of Remote-possibility makers}

(3) is there a cigarette on you?

(4) will there be a cigarette on you?

(5) would you have a cigarette?

Sentence (3) is relatively rude because it rise the implicative that $\mathrm{H}$ likely has a cigarette. In contrast with sentences (4) and (5), they avoid this implicative and consequently considerably more polite. Other encodings of polite pessimism in English are found in negative usage like (7) I don't \{imagine/suppose\} there'd be any \{chance/ possibility/ hope\} of you have any cigarette

Sentence (7) show that the speaker avoiding to be rude by inserting an adverbial word that indicates an uncertain. The adverbs usually used are supposed, imagine, change, possibility, hope, think (thought), and perhaps. The adverbial word to assume an unhelpful or uncooperative response.

\section{The Factor influencing the coice of strategies}

The speakers would have already mastered one of the most effective politeness strategies. Whereas, Hobjila (2012) mentions in her journal that with the use of the specific strategy of politeness, the threat addressed to a specific "face" is avoid or minimize. Several factors influence the use of politeness strategies. Three elements impact the speaker to adopt politeness strategy, according to Brown and Levinson (1987 in Djatmika, 2016: 6164). The variables include power (P), social distance (D), and imposition size (R) (Hidayati, 2017).

\section{Relative Power (P)}

The concept of power $(\mathrm{P})$ refers to the fact that we are more respectful to persons who have power or control over us than to those who do not. In a given setting, people are more likely to speak differently to their social equals than to 
individuals whose position is higher or lower than their own. The higher a person's power, the greater his or her rights to speak directly to the listener in conversation. Anyone with influence in various cultures will be able to directly contribute to the interaction that is taking place.

\section{Social Distance (D)}

Social distance (D) is a composite of psychologically real elements such as status, age, sex, and intimacy level, which combined influence the overall level of respect in a specific speech circumstance. In his publication, Setiawan (2016) noted that the social distance between speakers has a significant impact on how they communicate with one another. Distinguish between a buddy and a stranger, even if you share the same social rank but are separated by social distance. As a result, the farther we are from people, the more indirect speech act strategies we use. The greater the social distance, the more direct speech act strategies are employed. Social distance is defined by the existence of familiarity or unfamiliarity between hearer and speaker. Social distance is a degree of closeness (Khan,2016).

Size of imposition (R)

The relative status of one speech act to another in a context can reveal some impositions (R). When someone leans on the hearer in a conversation, the amount of the imposition will lead to the usage of politeness, whether positive or negative politeness. In this scenario, the word of imposition can refer to services or a desired action to be conducted by the hearer for the advantage of a first-person, or even a desirable thing in the hearer's interests. The more indirect strategies utilized to hold a conversation, the larger the amount that will be charged to the hearer. Conversely, the smaller a speaker is, the more likely he or she is to be direct.

\section{RESULT AND DISCUSSION}

The pessimistic strategy in Thor Ragnarok's film has been analysed based on theory in Brown and Levinson's book (1987) of universal politeness. In addition to explaining the Pessimistic strategies applied by actors, this subchapter also describes factors that affect actors or speakers delivered pessimistic strategies to opponents or listeners.

\section{The Types of the pessimistic strategy in negative politeness}

\section{The Use of Negative}

Example 1:

Thor: Are you well, Eric?

Selvig: Your brother not coming, is he?

Thor: Loki is dead

In this utterance, Selvig is the speaker and Thos is the hearer. Having a look at the utterance, the speaker uses a Tag question. Selvig as the speaker assumes that Thor will come with his brother. Meanwhile, he doesn't want Thor's brother Loki to come because he doesn't like it. He used the tag-question to express his doubts about Loki's arrival.

\section{The Use of Subjunctive}

\section{Example 2:}

College Girl 2: Ask him.

College Girl 1: Hi. Would you mind taking a picture with us?

Thor: Sure.

This utterance shows that the college girl as the speaker and the hearer is Thor. The speaker used the word "would" to save the negative face of the hearer. The speaker assumes that Thor not willing to accept her request, then she uses politeness.

Example 3:

Loki: My dear friend, if you were to give me twelve hours I could bring them both back to you. 
Valkyrie: I can do it in two

The characters in the above utterance used the If clause. The character Loki as the speaker presupposes that the hearer will not give him a chance. He uses the If clause to redressing the hearer or the target's negative face.

\section{The Use of Remote-Possibility Makers}

Example 4:

Thor: I suppose I'll need my brother back.

Dr. Strange: Yeah, right.

Referring to the utterance above, the speaker used the word "suppose" to explicitly expressing his doubt. Adding doubt in his utterance means he assuming the hearer not willing to bring back his brother.

Example 5:

Thor: You must be Hela. I'm Thor, son of Odin.

Hela: Really, you don't look like him.

Loki: Perhaps we can reach an arrangement.

Hela: You sound like him.

The above utterance shows that the speaker tries to make his word convincing to the hearer. The word "perhaps" also assume that the hearer is not willing to do the request, then the speaker applies the pessimistic strategy to save the negative face of the hearer.

\section{The factors influence the characters Relative Power}

Example 6

Thor: We're looking for my father.

Dr. Strange: So. If you were to tell you where Odin was, all parties concerned would promptly return to Asgard?

Thor: Promptly.

The above utterance shows that the speaker uses the subjunctive. The factor that influences the character used this strategy is the relative power. It could be seen if Thor has stronger power in this utterance than Dr. Stange because Dr. Stange needs Thor to accepted his want, and Thor has the power to accepted or rejected the request.

\section{Size of Imposition}

Example 7:

Thor is rolling down the stairs. A magic portal leading into a peaceful meadow has opened beside Dr. Strange.

Thor: We could have just walked

Having a look at the above utterance, the speaker used subjunctive. The character Thor influence by the size of imposition. Thor's desire is heavier to accepted by the hearer, then because of that factor the speaker should use that strategy to increase the probability of the hearer will accept the request.

\section{Social Distance.}

Data 12

Thor: The sun's going down. It's getting really low. The sun's going down. It's getting real low.

Banner: Would you stop saying that!?

Thor: I just need you to stay calm.

The above utterance shows that the speaker uses the subjunctive. The character used this strategy because he is influenced by social distance. The farther the social distance, the speaker will be more polite to the hearer. But here, Thor is close to Banner but in this case, Banner is not in a good situation to talk, then their distance becomes farther. Thor used this strategy because of the farther of their social distance.

\section{CONCLUSION}

Based on the foregoing analysis, it can be concluded that in Thor: Ragnarok Movie the characters used the pessimistic strategy is negative politeness. The types of pessimistic strategy found in the movie are the use of negative, the use of the subjunctive, and the use of remotepossibility makers. The use of negative could be found in the use of Tag question, the use of subjunctive was found in the use of Would, Should, and If 
clause, and the use of remote-possibility makers were found in the use of perhaps and suppose. Besides, The relative power, the size of the imposition, and the character's social status are all aspects that influence the character's deployment of the pessimistic strategy. Brown and Levinson's theory was applied in this research. (1987). The writer should examine more deeply Negative politeness applications because in the book written by Brown and Levinson's many other phenomena cannot be found in this data. Writers can apply this theory to various types of data sources such as official speeches, novels, or newspapers.

\section{REFERENCES}

Brown, P., \& S, Levinson. (1987). "Politeness Some Universals in Language Usage". Cambridge University Press.

Dewi, N. N. R. (2017). Negative Politeness Strategy Used in The Movie "Sex And The City". Humanis, English Department. Udayana University.

Widiadnyana, I. W., Sudipa, I. N., \& Dewi, A. A. S. S. (2016). Function and Meaning of Politeness on Movie "Hotel Transylvania". Humanis, English Department. Udayana University

Setiawan, G.A., Artawa, K., \& Widiastuti ,N. M. A. (2016). Negative Politeness Strategies Used By Characters in "Twilight" Movie Script. Humanis, 17(1)

Hariri, N. A. (2017). An Exploratory Sociolinguistic Study of Key Areas For Politeness Work In Saudi Academic Emails. School of English University of Leicester.
Hidayati, M. C. (2017). An Analysis of Positive Politeness Strategy in The Film Entitled The Jarkoni and Its Education Value. The State Islamic Institute of Surakarta.

Supriyanta, I. G. (2017). An Analysis of Politeness Strategies Used by Claire Peterson in The Big Next Door Movie. Sarjanawiyata Tamansiswa University.

Kusuma, A. (2014). Politeness Strategies In Barrac Obama Speech In Democratic National Convention 2012. Maulana Malik Ibrahim State University Of Malang

Aseptari, Ni Nengah. Terms Of Address And Politeness Used To Address Customers A Get Move Disc 3 and Get Mor Disc. Humanis, (S1) Dec 2012

Mahayani, N. W. I \& N. K. S. Rahayuni. (2018). Positive Politeness Straegies in James Corden's Interview on Recode Decode Talkshow. Humanis 22,(3), P. 781785.

Putra, I M. A. R. (2018). Positive Politeness Priniple in the Movie "The Last Song" by Nicolas Spark. Humanis, 22,(3), P.683-688.

Trimandala, N. A., Udayana, I N. \& Qomariana, Y. (2016). Politeness Strategies Used by the Main Character in the Movie "The Great Gatsby". Udayana University. Vol 16(2).

Hartati, S. (2020). Negative Politeness Strategies of Ahok's Statements in Mata Najwa Talkshow. Gunadarma University. 
Wati, N. L. H. R., \& Puspani, I. A. M. (2020). Positive Politeness Strategies Used by The Character in The Movie The Patriot. Udayana University. Humanis, 24(1).

Norra, R. N. (2015). An analysis of Politeness Strategies in $\mathrm{Her}$ movie. State Islamic University Syarif Hidayatullah.

Maskuri, K. D. S., Tarjana, S., Djatmika, \& purwanto, D. (2019). Politeness strategies in directive speech acts in lokal indonesian parliament assembly proceedings. Sebelas maret university.

Gilks, k. (2009-2010). Is the brown and levinson (1987) model of politeness as useful and influential as originally claimed? As assessment of the revised brown and levinson (1987) model. The university of nottingham, vol. 2.

Hobjila, A. (2012). Positive Politeness and Negative Politeness in Didactic Communication-Landmarks in Teaching Methodology. Alexandra Loan Cuza University.

Ulfa, N. (2019). Politeness Strategies and Cooperation Principle in "Wonder" Movie. International Journal of Education And Research, Vol. 17(7).

Khan, Z. M., \& Anwar, M. N. (2016). Analysis of Positive and Negatife Strategies in Trum's Interview To New York Times. Governmen M. A. O. College, Lahore. 